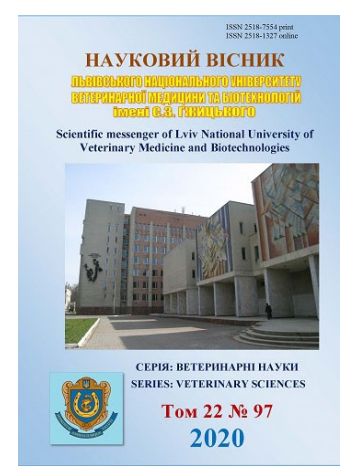

Науковий вісник Дьвівського національного університету ветеринарної медицини та біотехнологій імені С.3. Гжицького.

$$
\text { Серія: Ветеринарні науки }
$$

\section{Scientific Messenger of Lviv National University of Veterinary Medicine and Biotechnologies. Series: Veterinary sciences}

doi: 10.32718/nvlvet9714 https://nvlvet.com.ua/index.php/journal

UDC 618.46:611.013.8:636.2

\title{
Influence of complex action of probiotic and specific prophylaxis of associated mucosal diseases on some quantitative traits of dairy cattle performance
}

\author{
S. O. Sidashova ${ }^{1}$, B. V. Gutyj ${ }^{2}$, V. I. Khalak ${ }^{3}$, O. G. Humeny ${ }^{4}$ \\ ${ }^{1}$ Institute of Animal Breeding and Genetics nd. a. M. V. Zubets of National Academy of Agrarian Science of Ukraine; \\ Agricultural Advisory Service of Odessa region, Odessa, Ukraine \\ ${ }^{2}$ Stepan Gzhytskyi National University of Veterinary Medicine and Biotechnologies Lviv, Ukraine \\ ${ }^{3}$ State Institution "Institute of Cerealsof NAAS of Ukraine”, Dnipro, Ukraine \\ ${ }^{4}$ Odessa State Agrarian University, Odessa, Ukraine
}

Article info

Received 03.02.2020

Received in revised form 02.03.2020

Accepted 03.03.2020

Institute of Animal Breeding and Genetics nd. a. M.V. Zubets of National Academy of Agrarian Science of Ukraine,

Pohrebnyaka Str., 1, Chubynske, Boryspil region, Kyiv district, 08321, Ukraine.

Agricultural Advisory Service of Odessa region, Odessa, Ukraine.

Stepan Gzhytskyi National University of Veterinary Medicine and Biotechnologies Lviv, Pekarskaya Str., 50, Lviv, 79010, Ukraine. Tel.: +38-068-136-20-54 E-mail:bvh@ukr.net

State Institution Institute of grain crops of NAAS, V. Vernadsky Str., 14 Dnipro, 49027, Ukraine. Tel.: +38-067-892-44-04 E-mail:v16kh91@gmail.com

Odessa State Agrarian University, Panteleymonyvska, Str., 13, Odessa, 65012, Ukraine.
Sidashova, S. O., Gutyj, B. V., Khalak, V. I., \& Humeny, O. G. (2020). Influence of complex action of probiotic and specific prophylaxis of associated mucosal diseases on some quantitative traits of dairy cattle performance. Scientific Messenger of Lviv National University of Veterinary Medicine and Biotechnologies. Series: Veterinary sciences, 22(97), 79-87. doi: 10.32718/nvlvet9714

The article presents the results of studies of indicators of reaching the age of the first calving of repair heifers of the Ukrainian red dairy breed under the conditions of use of the complex scheme of specific immunoprophylaxis and preparation "Multibacterin veterinary suspension". The research was conducted in the conditions of the industrial complex for milk production of Dolinskoye LLC, Odessa region. The subjects of the study were groups-analogues of breeding heifers and the firstborn of the genotype.The assessment of repair young growth indicators was performed taking into account the following indicators: age of fertile insemination, months; age of first calving, months; milk production for 100 and 305 days of the first lactation, $\mathrm{kg}$. For the functional evaluation of the digestive status of animals used to determine the transit of feed, in \% and the assessment of acid-base status of faeces, $\mathrm{pH}$ unit. The following indicators were investigated in the serum of repair calves of mating age: total protein, $\mathrm{g} / \mathrm{l}$; albumin, $\mathrm{g} / \mathrm{l}$; globulin, $\mathrm{g} / \mathrm{l}$; glucose, mmol/l; urea, mmol/l; alkaline phosphatase, units/l and liver enzymes (ALT and AST, units/l).The economic efficiency of the results of the studies was calculated according to the indicator "average hope of one cow for 305 days of the first lactation, $\mathrm{kg}$ ". It was found that, due to the positive simultaneous effect of probiotic protection of the intestinal mucous membranes, repair heifers showed a higher growth and development rate and the first calving had 28.07 months, which is 2.31 months (8.45\%) earlier than in control $(P<0.001)$.The optimization of the technology of growing heifers for the use in the scheme of specific immunoprophylaxis of a probiotic drug - immunomodulator, which feed use had a prolonged positive effect not only on the growth parameters of young animals, but also on the increase of milk productivity per first lactation was experimentally proved.Calculations of cost-effectiveness of research results showed that the maximum increase in production (+9.10\%) was obtained from the firstborn of the experimental group born to cows mothers older than two lactations, where the scheme of specific prevention of associated diseases was carried out for repair heifers with previous normophilic laceration probiotic feed preparation.

Key words: repair heifers, probiotic multicomponent preparation, immunodeficiency, specific immunoprophylaxis, daily average gain, transit of feed.

\section{Вплив комплексної дії пробіотику та специфічної профілактики асоційованих хвороб слизових оболонок на деякі кількісні ознаки великої рогатої худоби молочного напрямку продуктивності}

\author{
С. О. Сідашова ${ }^{1}$, Б. В. Гутий ${ }^{2}$ В. І. Халак ${ }^{3}$, О. Г. Гуменний ${ }^{4}$
}


${ }^{1}$ Інститут розведення і генетики тварин НААН імені М. В. Зубия; Аграрна дорадча служба Одеської області, м. Одеса, Україна

${ }^{2}$ Львівський національний університет ветеринарної медицини та біотехнологій імені С. 3. Гжицького, м. Львів, Україна

${ }^{3}$ Державна установа “Інститут зернових культур НААН України”, м. Дніпро, Україна

${ }^{4}$ Одеський державний аграрний університет, м. Одеса, Україна

У статті наведено результати досліджень впливу комплексної дї пробіотика та специфічної профілактики асоційованих хвороб слизових оболонок на деякі кількісні ознаки великої рогатої худоби молочного напрямку продуктивності. Дослідження проведено в умовах промислового комплексу з виробництва молока ТОВ «Долинське» Одеської області. Об'єктами досліджень були групи-аналоги племінних ремонтних телиць та первістки зазначеного генотипу. Оцінку ремонтного молодняку за показниками росту проводили з урахуванням таких показників: вік плідного осіменіння, місяців; вік першого отелення, місяців; молочна продуктивність за 100 і 305 днів першої лактації, кг. Для функиіональної оцінки стану травлення тварин застосовували визначення транзиту кормів, в \% та оцінку кислотно-лужного стану фекалій, одиниці рН. У сироватці крові ремонтних телиць парувального віку досліджували такі показники: загальний протеїн, альбуміни, глобуліни, глюкозу, сечовину, лужну фосфатазу та печінкові ензими (АлАТ і АсАТ). Економічну ефективність результатів досліджень розраховували за показником “середній надій однієї корови за 305 днів першої лактащії, кг”. Встановлено, щзо ремонтні телиці внаслідок позитивного симультанного впливу пробіотичного захисту слизових оболонок кишківника показали вищий темп росту і розвитку та перше отелення мали в 28,07 місяия, щсо на 2,31 місяия (8,45\%) раніше, ніж в контролі $(P<0,001)$. Експериментально доведено оптимізацію технологї вирощування ремонтних телиць за використання в схемі специфічної імунопрофілактики пробіотичного препарату - імуномодулятора, кормове використання якого мало пролонговану позитивну дію не тільки на ростові параметри молодняку, а й на збільшення молочної продуктивності за першу лактацію в середньому на 60 к.. Розрахунки економічної ефективності результатів досліджень показали, ичо максимальну надбавку продукиії (+ 9,10\%) одержано від первісток дослідної групи, народжених матерями-коровами, щзо мали не менше ніж дві лактації, де схему специфічної профілактики асоційованих хвороб проводили для ремонтних телиць з попередньою нормофлоризацією слизових оболонок кииківника пробіотичним кормовим препаратом.

Ключові слова: велика рогата худоба, порода, ремонтні телиці, пробіотичний полікомпонентний препарат, імунодефіцит, специфічна імунопрофілактика, середньодобовий приріст, транзит кормів.

\section{Вступ}

Інтенсивність формування організму ремонтних теличок визначає майбутній рівень молочної продуктивності дійного поголів’я. У молочній галузі корови тільки після початку лактації починають компенсувати витрати на вирощування, при цьому ефективність секреції молока детермінована початковими етапами онтогенезу. Якісно вирощений ремонтний молодняк може бути додатковим елементом ефективності виробництва на весь термін продуктивної експлуатації (Humenny, 2001; Moskaleva, 2019).

Тому актуальність вирішення питання отримання i вирощення здорового приплоду постійно зростає за умови інтенсифікації виробництва. За останні роки суттєво підвищилась увага дослідників до вивчення взаємодії "макроорганізм-мікробіоценоз" в умовах промислового утримання тварин, де відмічено цілу низку негативних явищ: антибіотикорезистентність патогенних бактерій, преволюція мікроорганізмів, утворення патологічних асоційованих біоплівок, що у сукупності стали характеризуватися як “ушкоджуючі фактори" для організму тварин (Yong, et al., 2002; Costerton, 2007; Kreft, 2009; Moons et al., 2009; Hoibya et al., 2010). Українські і зарубіжні науковці вказують на невирішеність низки проблем стосовно ушкодження різних органів і систем організму тварин (поліорганні патології) за промислової експлуатації 3 причин низької ефективності схем симптоматичної терапії та комерційних вакцин за хронічних хвороб слизових оболонок, підгрунтям чого є значна генетична варіабельність асоціацій інфекційних агентів та латентного або субклінічного протікання хвороб (Yong, et al., 2002; Rublenko \& Vlasenko, 2011). Сучасні інтенсивні способи вирощування і експлуатації молочної худоби на всіх технологічних етапах виробництва провокують формування хронічних і часто глибоких імунодефіцитних станів, що здійснює непрогнозований вплив на формування поствакцинального імунітету і суттєво знижує реалізацію генетичного потенціалу високопродуктивної худоби (Patel \& DuPont, 2015; Biben, 2016).

На сучасному етапі розвитку промислового тваринництва все більшого поширення набувають ветеринарні схеми корекції імунопатологічного та імунодепресивного станів, що характеризують погіршення здоров'я молодняку і дійного поголів'я спеціалізованих молочних порід. На сьогодні доведено, що організм тварини у сукупності з його нормофлорою формує біологічну екосистему, здатну в стані фізіологічної норми до саморегуляції і самопідтримки за мінливих умов довкілля. У нормобіозі проективнокомпенсаторні та імунобіологічні механізми забезпечують превалювання в мікробіоценозах внутрішнього середовища макроорганізму нормальної постійної мікробіоти або нормофлори (Hoibya et al., 2010; Cutting, 2011; Biben, 2016).

В ситуації технологічного тиску на молодняк або вагітних корів, особливо за умов стаціонарно діючих стрес-факторів, наступає стан декомпенсації впливу негативних екзо- і ендогенних чинників, лабільна екосистема "макроорганізм-мікрофлора" втрачає фізіологічну стабільність видового і кількісного складу. Поверхні слизових різних порожнин макроорганізму, в основному кишківника, колонізуються нетиповими для цих органів видами умовно патогенної та потенційно патогенної мікрофлори, яка ініціює інфекційні процеси, що набули назву факторних, або асоційованих хронічних хвороб слизових оболонок (Moons et al., 2009; Cutting, 2011; Patel \& DuPont, 
2015). Дослідження українських науковців показують, що за низької ефективності етіологічної терапії цих хвороб особливу увагу потрібно приділяти специфічній профілактиці в ранньому віці тварин. Відмічені в літературі випадки недостатньої результативності масових обробок поголів'я 3 метою специфічної профілактики асоційованих хвороб слизових оболонок пов'язані як $з$ недосконалістю застосованих імуностимулюючих препаратів, так і з недостатньою вивченістю проблеми (Humenny, 2001; Humenny et al., 2007).

Зокрема, огляд літератури показує, що вплив дисбіозів слизових оболонок кишківника на результативність корекції імунопатологічних станів, особливо за масових і планових заходів імунопрофілактики, вивчено недостатньо.

За даними (Biben, 2016), симультанне застосування пробіотичних імуномодуляторів у системі протиепізоотичних заходів при масовому використанні вакцин супроводжується позитивними явищами в системі неспецифічної реактивності організму і підвищенням його імунологічної опірності, посиленням імунної відповіді на специфічний антигенний подразник, а також нормалізацією якісного і кількісного складу мікробіоти макроорганізму. На відміну від антибіотиків і хіміотерапевтичних препаратів пробіотики не виявляють негативного впливу на представників нормофлори, а за дисбіозів сприяють іiі якіснокількісному відновленню до фізіологічної норми (Jian, 2002; Biben, 2016).

Мета роботи - дослідити вплив комплексної дії пробіотиків та специфічної профілактики асоційованих хвороб слизових оболонок на деякі кількісні ознаки великої рогатої худоби молочного напрямку продуктивності.

\section{Матеріал і методи досліджень}

Експериментальну частину роботи проведено в ТОВ “Долинське” Одеської області. В господарстві розводять велику рогату худобу української червоної молочної породи. Продуктивність корів основного стада $(\mathrm{n}=600)$ становить: надій молока за 305 днів лактації - 6350 кг, вміст жиру - 4,0%. Об'єктом дослідження були ремонтні телиці та корови після першого отелення (n = 148 гол.). Умови утримання, вирощування і годівлі тварин відповідали сучасним зоогігієнічним правилам, все поголів'я було охоплене плановими протиепізоотичними заходами відповідно до чинних ветеринарних вимог. Зооветеринарні процедури проводили за умов чинних правил фіксації тварин (Instructionon ..., 2001; Sidashova, 2014; Sidashova et al., 2016). Дослідження проводили за методом періодів 3 комплектацією груп-аналогів.

Для аналізу зоотехнічних показників (вік плідного осіменіння ремонтних телиць, вік першого отелення, молочна продуктивність) використовували дані первинного зоотехнічного обліку (комп'ютерна база даних "Dairy Plan") та результати власних досліджень. Формування груп проводили за схемою: I (контроль- на) - ремонтні телички, народжені коровами другої та подальших лактацій; III (контрольна) - ремонтні телички, народжені нетелями; II (дослідна) - ремонтні телички (отримували курс пробіотиків per os), народжені коровами другої і подальших лактацій; IV (дослідна) - ремонтні телички (отримували курс пробіотиків per os), народжені нетелями. Інноваційність методичного підходу характеризувалась введенням у загальноприйняту технологію вирощування ремонтних телиць та підготовки їх до запліднення попереднього етапу нормофлоризації слизових кишківника.

Біохімічні показники сироватки крові тварин піддослідних груп досліджували за загальноприйнятими методиками в багатопрофільній лабораторії ветеринарної медицини Одеського державного аграрного університету. Оцінку рівня перетравності кормів в контрольних і дослідних групах проводили за методикою (Sidashova \& Gumenny, 2017).

Відповідно до розробленого в господарстві плану профілактики захворюваності поголів'я в усіх групах проводили за графіком вакцинацію експериментальним імустимулюючим препаратом, виготовленим із патологічного матеріалу тварин власного стада, у яких діагностовано клінічні симптоми хвороб слизових оболонок змішаної вірусно-бактерійної етіології (Humenny, 2001; Humenny \& Morozov, 2007; Sidashova, 2014). В дослідній групі ремонтних телиць додатково перед вакцинацією і до проведення штучного осіменіння була організована даванка кормового пробіотичного препарату “Мультибактерин ветеринарний суспензія" (Guidelines for..., 2003). Кормову суміш роздавали впродовж 40 днів один раз на добу шляхом розбризкування механічним аератором на свіжорозданий корм в годівниці (дозування відповідно до настанови виробника - 40 мл суміші на голову).

Фармакологічні особливості препарату “Мультибактерин ветеринарний суспензія" (полікомпонентні пробіотики - Lactobacillus acidophilus, Bacillus subtilis, Bifidobacterium adolescentis - $10^{9}$ м.т. $/ \mathrm{cm}^{3}$ ) придатні до застосування як замісна терапія для профілактики i лікування респіраторних, шлунково-кишкових захворювань тварин (колібактеріозу і сальмонельозу), дисбактеріозів, корекції мікрофлори шлунковокишкового тракту при антибіотикотерапії, мікотоксикозів, проявляють імуностимулюючу і ростстимулюючу дію. Розширення сфери застосування препарату в гінекології продуктивних тварин було перевірено в нашому попередньому виробничому дослідженні (Sidashova \& Gumenny, 2017). Препарат є екологічно чистим, не викликає ускладнень, не має побічної дії, не накопичується в органах і тканинах тварин; протипоказання не встановлені. Препарат можна використовувати паралельно із застосуванням інших терапевтичних засобів. Препарат виготовлений зі штамів мікроорганізмів, які не чутливі до цілого ряду антибіотиків.

Економічну ефективність проведених досліджень розраховували відповідно до загальноприйнятих методичних рекомендацій (The methodology..., 1983). 
Біометричну обробку результатів досліджень проведено за методикою (Lakin, 1990).

\section{Результати та їх обговорення}

Порівняння термінів першого отелення в групах контрольних і дослідних нетелів висвітило сталу тенденцію до зменшення строків вирощування ремонту за використання комплексної схеми специфічної профілактики асоційованих хвороб слизових оболонок ВРХ (табл. 1).
В досліді у середньому ввід первісток в дійне стадо наступив через $28,07 \pm 0,33$ місяця після народження, а в контролі - тільки через $30,3 \pm 0,45$ місяця $(\mathrm{P}<0,001)$. Беручи до уваги дані інших авторів щодо можливого впливу на ростові параметри теличок їх народження від нетелів або від повновікових корів, про що вказувалось в ряді публікацій (Moskaleva, 2019), ми відповідно структурували групи-аналоги в контролі та в досліді.

\section{Таблиця 1}

Вік першого плідного осіменіння та отелення ремонтних телиць

\begin{tabular}{|c|c|c|c|}
\hline Група та ії призначення & Біометричні показники & Вік першого отелення, міс. & Вік першого плідного осіменіння, міс. \\
\hline \multirow{4}{*}{ I (контрольна) } & $\mathrm{n}$ & 43 & 43 \\
\hline & $\mathrm{M} \pm \mathrm{m}$ & $30,87 \pm 0.659$ & $21,87 \pm 0,659$ \\
\hline & $\sigma$ & 4,32 & 4,32 \\
\hline & $\mathrm{Cv}, \%$ & 14,00 & 19,77 \\
\hline \multirow{4}{*}{ II (дослідна) } & $\mathrm{n}$ & 45 & 45 \\
\hline & $\mathrm{M} \pm \mathrm{m}$ & $27,66 \pm 0.406$ & $18,77 \pm 0,92$ \\
\hline & $\sigma$ & 2,72 & 2,62 \\
\hline & $\mathrm{Cv}, \%$ & 9,84 & 14,00 \\
\hline \multirow{4}{*}{ III (контрольна) } & $\mathrm{n}$ & 37 & 37 \\
\hline & $\mathrm{M} \pm \mathrm{m}$ & $29,66 \pm 0.614$ & $20,55 \pm 0,595$ \\
\hline & $\sigma$ & 3,736 & 3,715 \\
\hline & $\mathrm{Cv}, \%$ & 12,59 & 18,07 \\
\hline \multirow{4}{*}{ IV (дослідна) } & $\mathrm{n}$ & 23 & 23 \\
\hline & $\mathrm{M} \pm \mathrm{m}$ & $28,89 \pm 0,512$ & $19,98 \pm 0,484$ \\
\hline & $\sigma$ & 2,45 & 2,32 \\
\hline & $\mathrm{Cv}, \%$ & 8,49 & 11,62 \\
\hline
\end{tabular}

Як показав аналіз, терміни вирощування ремонтних телиць мали нелінійну динаміку в групах приплоду, отриманого від матерів-корів і матерів-нетелів. У групах первісток, народжених коровами, в досліді термін вирощування був коротшим, ніж в контролі, у середньому на 3,21 місяця $(\mathrm{td}=4,155 ; \mathrm{P}<0.001)$. Варто зазначити, що різниця між контрольними телицями, народженими від корів або нетелів, не мала статистичної вірогідності, а між двома дослідними групами кореляційні зв'язки вірогідні $(\mathrm{td}=1,807$; $\mathrm{P}<$ 0,05). Підтверджуючи дані інших авторів, наш ретроспективний аналіз засвідчив суттєвий вплив паратипових факторів на розвиток тварин впродовж тривалих науково-господарських досліджень.

Виходячи $з$ технологічного плану, прийнятого в підконтрольному господарстві, щодо переведення ремонтних телиць до групи відтворення після досягнення живої маси 350 кг, доцільно порівняти пожиттєвий щоденний приріст в контрольних і дослідних групах. В контролі до терміну плідного осіменіння $(21,31 \pm 0,46$ місяця) телиці мали в середньому 501 грам приросту живої маси щоденно, а в досліді 558 г (запліднення у віці 19,5 \pm 0,32 місяця). Варто зазначити, що в обох групах показники приросту не досягли оптимального рівня, який рекомендовано українськими науковцями для забезпечення фізіологічного підгрунтя високої продуктивності майбутньої корови (650-700 г), що підтвердило значний тиск паратипових факторів.
Проблема специфічного захисту організму тварин від інфекційних захворювань завжди стояла дуже гостро і особливо за вірусних інфекцій. Разом 3 тим до цього часу створення активного імунітету за низкою асоційованих інфекційних захворювань залишається проблематичним не лише 3 практичної точки зору, а й з теоретичної (Humenny, 2001; Humenny \& Morozov, 2007). Головною причиною цього є специфічність ряду складових змішаних хронічних інфекцій, а саме збудників вірусної етіології (наприклад, інфекційного ринотрахеїту, який мав у стаді клінічний прояв у вигляді пустульозного вульвовагініту IPТ-ПВВ). 3 іншого боку, в умовах промислового утримання з постійними стресами для тварин формується неспроможність організму забезпечити повноцінну імунну відповідь на дію подібних пошкоджуючих факторів, пов'язаних з процесами преволюції у мікробіоценозах сучасних тваринницьких комплексів (Costerton, 2007; Hoibya et al., 2010; Rublenko \& Vlasenko, 2011). Однією $з$ основних причин, що унеможливлюють повноцінне використання всього потенціалу специфічного захисту організму тварин, $\epsilon$ імунодефіцити - як генетично обумовлені, так і набуті.

Хронічні асоційовані інфекційні хвороби, зокрема і IPТ-ПВВ, в підконтрольному стаді мали перебіг на фоні постійного, а іноді навіть глибокого порушення обміну речовин в організмі тварин та імунного дефіциту. Нами було досліджено фоновий біохімічний склад сироватки крові ремонтних телиць, що показу- 
вав характерні метаболічні відхилення в організмі тварин у період перед проведенням штучного запліднення (табл. 2).

В сироватці крові ремонтних телиць встановлено функціональний рівень відхилень в білковому складі, а саме: гіперпротеїнонурію (вміст загального протеїну - 77,68 г/л порівняно з 55-75 г/л в нормі), до того ж суттєві відхилення у співвідношенні різних протеїнових фракцій (протеїновий коефіцієнт 2,25 одиниці порівняно з 0,6-1,1 одиниці в нормі). Подібні дисфункціональні відхилення характеризують процеси хронічного інфекційного запалення в організмі тварин, що візуально встановлено у вигляді катарального запалення слизових оболонок вульви (пустульозний вульвовагініт), клінічна картина якого часто має нечіткі симптоми і проходить поза увагою ветеринарної служби.

Таблиця 2

Біохімічні показники сироватки крові ремонтних телиць парувального віку

\begin{tabular}{|c|c|c|c|c|c|}
\hline \multirow{2}{*}{ Показники } & \multirow{2}{*}{$\mathrm{n}$} & \multirow{2}{*}{$\mathrm{M} \pm \mathrm{m}$} & \multicolumn{2}{|c|}{$\lim$} & \multirow{2}{*}{ Норма } \\
\hline & & & $\min$ & $\max$ & \\
\hline Загальний протеїн, г/л & 6 & $77,68 \pm 1,02$ & 64 & 153 & $55-75$ \\
\hline Альбумін, г/л & 6 & $44,50 \pm 1,02$ & 44 & 45 & $30-35,5$ \\
\hline Глобулін, г/л & 6 & $20,00 \pm 1,11$ & 19 & 21 & $30-35$ \\
\hline Протеїновий коефіцієнт, од. & 6 & $2,25 \pm 1,14$ & 2,1 & 2,4 & $0,6-1,1$ \\
\hline АлАТ, од./л & 6 & $93,5 \pm 1,15$ & 87 & 100 & $10-40$ \\
\hline АсАТ, од./л & 6 & $16,5 \pm 2,67$ & 9 & 24 & $10-50$ \\
\hline Глюкоза, ммоль/л & 4 & $2,60 \pm 1,04$ & 2,5 & 2,6 & $2,5-4,16$ \\
\hline Сечовина, ммоль/л & 6 & $2,95 \pm 1,03$ & 2,9 & 3,0 & $2,8-5,8$ \\
\hline Креатинін, кмоль/ & 4 & $157,5 \pm 1,01$ & 90,7 & 232,6 & $45-140$ \\
\hline Лужна фосфатаза, од./л & 6 & $219,3 \pm 1,09$ & 209,5 & 229 & $20-150$ \\
\hline
\end{tabular}

Помітне зростання активності печінкового ензиму АсАТ свідчило на початок розвитку патології печінки. Дуже симптоматичним виявилось суттєве підвищення показника лужної фосфатази до 219,3 од./л порівняно 3 20-150 од./л за нормою. 3 діяльністю цього ензиму-каталізатора пов'язана регуляція клітинної проникності, висока активність його в ендотеліальних клітинах кровоносних судин свідчить про дуже важливу роль цього ензиму в механізмах регуляції мінерального, ліпідного і білкового обмінів між кров'ю та навколишніми тканинами (Gutyj et al., 2018; Slivinska et al., 2018; Khalak et al., 2019; Varcholyak \& Gutyi, 2019). За участю лужної фосфатази йде процес ресорбції жирів і вуглеводів в слизовій оболонці тонких кишок. У нирках же вона бере участь у ресорбції глюкози $з$ нефрону (Kudrin, 2006; Yong et al., 2002). Вірогідно, отримані дані біохімічного складу крові, зокрема параметри лужної фосфатази і креатиніну, маніфестують процеси пошкодження і високої проникності епітеліальних клітин слизових оболонок різних порожнин для шкідливих речовин, зокрема бактерійних токсинів, що характеризує патогенез за асоційованих інфекційних хвороб слизових оболонок. За даними ряду авторів, зниження опірної і бар'єрної функції слизових оболонок травного тракту провокує інтралокацію патогенів гематогенно-лімфогенним шляхом до різних систем організму, що формує стан поліорганної патології і суттєво знижує адаптивність тварин в умовах промислових технологій утримання (Cutting, 2011).

За даними білоруських дослідників (Moskaleva, 2019), встановлено, що у телят, отриманих від низько резистентних корів, були відхилення від норми в біохімічних показниках крові порівняно з ровесниками від корів з високою резистентністю. Зокрема, експе- рименти 3 вивчення резистентності організму молочної худоби показали, що захисні сили тварин є динамічними показниками і визначаються як генетичними особливостями, так і впливом різних факторів довкілля.

Явище імунного дефіциту досить добре вивчено при різних інфекційних захворюваннях і більшість дослідників схильні до думки щодо необхідності застосовування стимуляторів захисних факторів організму як специфічних, так і неспецифічних (Davey \& O'Toole, 2000; Dubuc et al., 2010; Kasimanickam et al., 2016). Пробіотики активізують імунну систему, регулюючи функції гуморального і клітинного імунітету стимулюють вироблення імуноглобулінів, інтерферону, цитокінів, інтерлейкінів, посилюють активність макрофагів, гранулоцитів, що у сукупності оптимізує метаболізм макроорганізму.

Експрес-контроль кислотно-лужних показників фекальних мас у ремонтних телиць в досліді після 4060 днів згодовування композиції симбіотичних бактерій у складі пробіотичної кормової суміші становив $7,34 \pm 0,10$ одиниці ( $\mathrm{n}=19$ проб, оцінених з використанням лакмусових паперових смужок). В контролі без використання пробіотичного захисту слизових кишківнику телиць ( $\mathrm{n}=19)$ середній показник становив 7,26 $\pm 0,181$ одиниці. Різниця між групами не мала вірогідної кореляції, але симптоматичним було порівняння флуктуації показників: в контролі від 6,00 до 9,00 одиниць, в досліді - від 7,00 до 8,50 одиниці, що свідчило за нестабільність кислотно-лужного стану хімусу кишківника у телиць, які не отримували додаткової кількості кисломолочних бактерій разом 3 пробіотичною добавкою.

Здатність лактобактерій Lactobacillusacidophilus до нормалізації кислотно-лужного середовища вмісту 
кишківника доведено в численних експериментах, що підтвердилось показниками дослідних груп. Після додаткового внесення молочнокислих культур і колонізації слизової травного тракту культурами симбіотичних бактерій пробіотичного препарату, проявився ефект підвищення бар'єрної функції власної мікробіоти кишківника молодняку. Після курсу кормової пробіотичної нормофлоризації у дослідних телиць кисло- тно-лужний стан фекалій коливався в межах фізіологічної норми (Sidashova et al., 2016).

Регуляторну роль додаткового внесення в кишківник телиць симбіотичної нормофлори та формування фізіологічно активної популяції підтвердили дані оцінки рівня транзиту кормів після 40-60-денного періоду даванки кормової пробіотичної суміші (табл. 3).

\section{Таблиця 3}

Динаміка транзиту кормів в фекаліях ремонтних телиць у групах, де проводили даванку кормових пробіотиків $\mathrm{i}$ без неї (через 40-60 днів після початку даванки кормової суміші “Мультибактерин ветеринарний суспензія”)

\begin{tabular}{|c|c|c|c|}
\hline Показники, одиниці виміру & Біометричні показники & Контроль & Дослід \\
\hline \multirow{4}{*}{ Загальний транзит кормів, \% } & $\mathrm{n}$ & 6 & 5 \\
\hline & $\mathrm{M} \pm \mathrm{m}$ & $49,50 \pm 2,078$ & $32,20 \pm 3,639$ \\
\hline & $\sigma$ & 5,08 & 8,13 \\
\hline & $\mathrm{Cv}, \%$ & 10,28 & 25,26 \\
\hline Lim: min, одиниць & - & 43 & 18 \\
\hline max, одиниць & - & 57 & 38 \\
\hline
\end{tabular}

Суттєве зниження кількості неперетравлених залишків кормів на $17,30 \%(\mathrm{td}=4,129 ; \mathrm{P}<0,01)$ в фекаліях дослідної групи свідчило за те, що композиція молочнокислих культур Lactobacillus acidophilus $i$ Bifidobacterium adolescentis здатна впливати на ефективність продукування травних ензимів після колонізації слизових кишківника телиць. Високу здатність симбіотичної молочнокислої мікрофлори вказаного препарату було попередньо показано в експериментах на відгодівлі бройлерів 3 перевіркою ефективності специфічної профілактики інфекційних хвороб птиці .

Варто відмітити біологічну особливість застосованої композиції пробіотичних культур, а саме: першим при попаданні на слизові макроорганізму розпочинає активну дію транзиторний штам Bacillus subtilis, що перебуває у складі суміші в рідкій формі і здатен до максимального розмноження вегетативних форм вже через одну годину після згодовування препарату (Guidelines for..., 2002). За даними численних експериментів відомо, що Bacillus subtilis вирізняється високою здатністю до біотрансформації різноманітних токсинів, тому він швидко знебруднює поверхню слизових кишківника тварин від токсичних метаболітів патогенних бактерій і мікотоксинів. Водночас ця культура виділяється здатністю до продукування значної кількості антибіотикоподібних сполук та інших протимікробних речовин, що в кишківнику діють на патогенну мікрофлору вибірково, не пошкоджуючи представників власної мікробіоти тварини (Cutting, 2011; Bai et al., 2017). Таким чином, Bacillus subtilis готує слизову кишківника для швидкої колонізації іншими компонентами препарату, а саме: молочнокислими бактеріями, які матимуть оптимальні умови до адгезії на ворсинках слизової кишківника, тим самим створюючи фізіологічно активний бар'єр, що стимулює ферментативні властивості кишківника загалом (Guidelines for..., 2002). Варто підкреслити відому біологічну особливість застосовуваної композиції мікроорганізмів щодо типового розподілу місць для адгезії на ворсинах кишківнику: Lactobacillus acidophilus розташовується у верхніх шарах, a Bifidobacterium adolescentis - в глибині крипт між ворсинками, що забезпечує ефективнішу протекторну дію з урахуванням функції транзиторного штаму Bacillus subtilis.

Це мало підтвердження в ході обстеження неперетравлених залишків гною ремонтних телиць в досліді. Зокрема, під час візуальної оцінки стану гною, було виявлено суттєве зменшення кількості слизу як характеристики хронічного запалення слизових кишківника, що було ознакою терапевтичної функції (детоксикаційної і протизапальної) пробіотичного захисту. В дослідженнях українських вчених на бройлерах, які споживали вказаний препарат в профілактичних цілях, було на гістологічних зрізах виявлено більш щільний стан клітин слизових і зростання товщини слизової оболонки, що поліпшувало всмоктування поживних речовин у кишківнику птиці.

Встановлені експериментально дані оптимізації обмінних процесів організму ремонтних телиць під час згодовування пробіотичного препарату дозволили оцінити позитивний вплив пробіотичного захисту слизових кишківника в сукупності з дією імуностимулюючого тканинного препарату в довгостроковій перспективі, а саме: ефективності реалізації генетичного потенціалу молочної продуктивності у майбутніх корів контрольних і дослідних груп після першого отелення (табл. 4).

Детоксична дія на організм, поліпшення живлення тканин сприяли оптимізації умов розвитку різних органів молодняку, зокрема розвитку морфофункціонального стану секреторних альвеол вимені.

Аналіз молочної продуктивності первісток дослідних груп встановив сталу тенденцію до збільшення надою як за період роздою, так і за стандартну лактацію, відповідно: I контроль - 2393 і 6763 кг молока, III дослід - 2517 і 6777 кг (за перші 100 і 305 днів лактації), II контроль - 2485 і 6766 кг і IV дослід 2642 і 6928 кг. Вірогідної різниці між групами не 
встановлено (відповідно $\mathrm{td}=0,784 \mathrm{i} \mathrm{td}=0,28 ; \mathrm{td}=$ $0,056$ i td $=0,510 ; \mathrm{P}>0,05)$, що може пояснюватися значним технологічним тиском умов промислового утримання тварин на морфофункціональні аспекти формування їхньої лактаційної функції. Про це свідчив той факт, що різниця між контролем і дослідом впродовж перших 100 днів лактації помітно більша, ніж в другій половині (на + 124-156 кг відповідно).

\section{Таблиця 4}

Оцінка рівня молочної продуктивності за 100 і 305 днів лактації у первісток контрольних та дослідних груп

\begin{tabular}{lccc}
\hline Група та ії призначення & Біометричні показники & $\begin{array}{c}\text { Середній надій за } 100 \\
\text { днів лактації }\end{array}$ & $\begin{array}{c}\text { Середній надій за 305 днів } \\
\text { лактації }\end{array}$ \\
\hline \multirow{2}{*}{ I (контрольна) } & $\mathrm{n}$ & 29 & 29 \\
& $\mathrm{M} \pm \mathrm{m}$ & $2393,1 \pm 132,43$ & $6763,50 \pm 170,22$ \\
& $\sigma$ & 713,15 & 916,70 \\
& $\mathrm{Cv} \%$ & 29,80 & 13,55 \\
\hline II (дослідна) & $\mathrm{n}$ & 29 & 29 \\
& $\mathrm{M} \pm \mathrm{m}$ & $2517,24 \pm 86,71$ & $6777,45 \pm 178,84$ \\
& $\sigma$ & 466,93 & 963,08 \\
III (контрольна) & $\mathrm{Cv} \%$ & 18,54 & 14,21 \\
& $\mathrm{n}$ & 28 & 28 \\
& $\mathrm{M} \pm \mathrm{m}$ & $2485,54 \pm 86,52$ & $6766,25 \pm 175,118$ \\
IV (дослідна) & $\sigma$ & 457,42 & 926,63 \\
& $\mathrm{Cv} \%$ & 18,76 & 13,69 \\
\hline
\end{tabular}

Застосоване в господарстві удосконалення технології вирощування ремонтних телиць за симультанного впливу специфічної імунопрофілактики на фоні пробіотичного захисту слизових оболонок кишківника підтвердило високі імуномодуляторні властивості композиції мікроорганізмів полікомпонентного препарату - кормосуміші "Мультибактерин ветеринарний суспензія”. Вірогідно, пролонгований позитивний вплив додатково внесеної мікрофлори забезпечив утворення сталої метаболічно активної популяції пробіотичних бактерій у травному тракті тварин, що позитивно вплинуло на ріст і розвиток різних систем організму молодняку, зокрема секреторної функції вимені. Але морфологічні особливості формування тканин органів за симультанного впливу вказаної схеми ще потребують подальших досліджень на гістологічному та цитологічному рівні.

Зважаючи на сталий попит власників молочних комплексів на якісний ремонтний молодняк сучасних молочних порід, впровадження результатів експериментальної схеми комплексної імунопрофілактики в підконтрольному господарстві дозволило прискорити процес вирощування ремонтних телиць і мати для продажу поголів'я виранжированих за селекційними ознаками теличок. За загальноприйнятою методикою (The methodology for... 1983) було розраховано економічну ефективність за результатами досліджень (табл. 5).

\section{Таблиця 5}

Економічна ефективність результатів досліджень

\begin{tabular}{|c|c|c|c|}
\hline Групи & $\mathrm{n}$ & $\begin{array}{c}\text { Середня молочна продуктивність за } \\
305 \text { днів лактації, кг }\end{array}$ & $\begin{array}{c}\text { Надбавка продукції, } \\
\text { \%* }\end{array}$ \\
\hline В середньому по дійному стаду & 600 & 6350,00 & - \\
\hline I (контрольна) & 29 & 6763,50 & $+6,50$ \\
\hline II (дослідна) & 29 & 6777,45 & $+6,72$ \\
\hline III (контрольна) & 28 & 6766,25 & $+6,55$ \\
\hline IV (дослідна) & 14 & 6927,64 & $+9,10$ \\
\hline
\end{tabular}

Примітка: * - станом на період проведення розрахунку ціна реалізації молока до молокопереробного підприємства за договором з господарством становила 12,00 грн за 1 кг

Розрахунки економічної ефективності результатів досліджень показали, що максимальну прибавку продукції (+ 9,10 \%) отримано від первісток IV дослідної групи.

\section{Висновки}

1. Вплив симультанної дії пробіотичного захисту слизових кишківника за згодовування кормової суміші симбіотичних культур бактерій (Lactobacillus acidophilus, Bifidobacterium adolescentis, Bacillus subtilis) ремонтним телицям в схемі 
специфічної імунопрофілактики асоційованих хвороб слизових оболонок сприяв реалізації генетичного потенціалу продуктивності первісток української червоної молочної породи: в досліді надій на корову за 305 днів лактації склав 6777,45-6924,64 кг молока, що більше, ніж в контролі, на 14-162 кг, або на 6,75$9,10 \%$

2. Удосконалена схема специфічної імунопрофілактики асоційованих інфекційних хвороб слизових оболонок за комплексного застосування пробіотичного полікомпонентного препарату “Мультибактерин ветеринарний суспензія" підвищила інтенсивність вводу первісток в дійне стадо на 3,21 місяця раніше порівняно з контролем.

3. Максимальну добавку додаткової продукції (середній надій на корову за 305 днів першої лактації, кг) одержано в дослідній групі первісток, народжених від матерів-корів не молодше другої лактації $(+9,10 \%)$.

4. Застосування пробіотичного препарату кормової суміші “Мультибактерин ветеринарний суспензія" в схемі специфічної імунопрофілактики інфекційних хвороб ремонтних телиць висвітило перспективний напрямок інтенсифікації вирощування племінної худоби в умовах молочних промислових комплексів.

5. Для вивчення пролонгованої дії на організм тварин композицій симбіотичних культур у складі пробіотичних препаратів необхідні подальші дослідження процесів взаємодії “макроорганізммікроорганізми" на гістологічному і цитологічному рівнях.

\section{References}

Bai, K., Huang, N., Zhang J., He J., Zhang L., \& Wang T. (2017). Supplemental effects of probiotic Bacillus subtilis FMBJ on growth performance, antioxidant capacity, and meat quality of broiler chickens. Pouit. Sci., 96(1), 74-82. doi: 10.3382/ps/pew246.

Biben, I. A. (2016). Influence of a biotic preparation from crops and on the immune response of broiler chickens. Scientific and Technical Bul. IBT and DNKI veterinaryproductsandfeedadditives, 17(2), 181-186 (in Ukrainian).

Costerton, J. W. (2007). The Biofilm Primer. Berlin: Springer. https://www.springer.com/gp/book/9783540680215.

Cutting, S. M. (2011). Bacillus probiotics. Food Microbiol, 28(2), 214-220. doi: 10.1016/j.fm.2010.03.007.

Davey, M. E., \& O'Toole, G. A. (2000). Microbial biofilms: from ecology to molecular genetics. Microbiol Mol Biol Rev, 64(4), 847-867. doi: 10.1128/mmbr.64.4.847867.2000.

Dubuc, J., Duffield, T. F., Leslie, K. E., Walton, J. S., \& LeBlanc, S. J. (2010). Risk factors for postpartum uterine diseases in dairy cows. J Dairy Sci., 93(12), 5764-5771. doi: 10.3168/jds.2010-3429.

Guidelines for the use of the drug Multibacterin veterinary (mono- and poly component probiotics). Approved by the Scientific Council of the State Scientific
Research Institute of Veterinary Medicines and Feed Additives (Minutes No. 2 of February 12, 2003).

Gutyj, B., Grymak, Y., Hunchak, V., Mysak, A., Nazaruk, N., Brezvyn, O., Hariv, I., Shcherbatyy, A., Semeniv, B., Bushueva, I., Parchenko, V., Kaplaushenko, A. (2018). Preclinical searches of the preparation Thireomagnile. Ukrainian Journal of Ecology, 8(1), 688-695. doi: 10.15421/2018_267.

Hoibya, N., Bjarnsholt, T., Givskov, M., Molin, S., \& Ciofu, O. (2010). Antibiotic resistance of bacterial biofilms. Int. J. of Agents., 35(4), 322-332. doi: 10.1016/j.ijantimicag.2009.12.011.

Humenny, O. G. (2001). Some indicators of immunological reactivity of the body of cows and heifers, patients with IRT-PVV, with the combined use of vaccines and immunostimulants. Veterinary medicine of Ukraine, 11, 34-35 (in Ukrainian).

Humenny, O. G., \& Morozov, M. G. (2007). Forms and clinical manifestation of IRT - PVV in the farms of Odessa region. Agrarian Bulletin of the Black Sea: Coll. of sciences. works of the Odessa State Tax Administration. Veterinary Science, 39, 48-53 (inUkrainian).

Instruction on artificial insemination of cows and heifers. K., 2001, 38 p. (in Ukrainian).

Jian, L. (2002). Bacterial Resistance to Antimicrobials: Mechanisms, Genetics, Medical Practice and Public Health. Biol. Let., 24(10), 801-805.

Kasimanickam, R., Koziv, R., \& Lototskiy, V. (2016). Postpartum uterine diseases in dairy cows. Visnyk Bilocerkiv. derzh.agrar. in-tu. Bila Cerkva, 2, 11-16.

Khalak, V. I., Gutyj, B. V., \& Stadnits'ka, O. I. (2019). Feeding and meat qualities of young pigs of different origin and intensity of formation in early ontogenesis. Scientific Messenger of Lviv National University of Veterinary Medicine and Biotechnologies. Series: Agricultural sciences, 21(91), 10-15. doi: 10.32718/nvlvet-a9102.

Kreft, J.-U. (2009). Biofilms promote altruism. Microbiology, 150(8), 2751-2760. doi: 10.1099/mic.0.26829-0.

Kudrin, A. G. (2006). Blood enzymes and prediction of the productivity of dairy cattle. Publishin ghouse of FGOU VPO. Michurinsk GAU (in Russian).

Lakin, H. F. (1990). Biometriya: uchebnoe posobiye [dlia biol. Ssets. vuzov]. Moskow, Vysshaya shkola (inRussian).

Moons, P., Michiels, C.W., \& Aertsen, A. (2009). Bacterial interactions in biofilms. Crit. Rev. Microbiol., 35(3), 157-168. doi: 10.1080/10408410902809431.

Moskaleva, E. N. (2019). Influence of various factors on the natural resistance of calves. Sat. Scientific article son the mat. Int. scientific and practical conf. 70th anniversary of the Republican Unitary Enterprise "Scientific and Practical Center of the National Academy of Sciences of Belarus for Livestock", Zhodino, December 19-20, 2019, Minsk, 155-159 (in Russian).

Patel, R., \& DuPont, H. L. (2015). New approaches for bacteriotherapy: Prebiotics, new generation probiotics, and synbiotics. Clin. Infect. Dis., 60(2), 108-121. doi: $10.1093 / \mathrm{cid} / \mathrm{civ} 177$. 
Rublenko, M. V., \& Vlasenko, S. A. (2011). Health Problems for High-Performance Cows. Veterinary medicine: between from. theme. of sciences. Sat. Kharkiv, 95, 397-400 (in Ukrainian).

Sidashova, S. O. (2014). Influence of tissue preparation on normalization of sexual function of heifers. Breeding and genetics of animals: between from. theme. of sciences. K.: Agrarian Science, 49, 236-247 (in Ukrainian).

Sidashova, S. O., \& Humeny, O. G. (2016). Influence on biotic protection of mucous membranes on the function of ovaries of lactating cows. Scientific Bulletin of Veterinary Medicine, 2(130), 17-24 (in Ukrainian).

Sidashova, S. O., Avdoseva, I. K., \& Grigorasheva, I. M. (2016). Probiotic protection of the mucous reproductive tract and dairy productivity of cows. Scientific and Technical Bul. IBT and DNKI veterinary products and feed additives, 16, 200-210 (in Ukrainian).

Sidashova, S., \& Gumenny, O. (2017). Rhythm of sexual cycles of cows and level of the hidden early embrionic mortality. Scientific Messenger of LNU of Veterinary Medicine and Biotechnologies. Series: Veterinary Sciences, 19(78), 121-128. doi: 10.15421/nvlvet7825.
Sidashova, S.O., Avdoseva, I. K., Grigorasheva, I. M. (2016). Probiotic protection of the mucous reproductive tract of lactating cows. Scientific and Technical Bul. IBT and DNKI veterinary products and feed additives, 16, 199-209. (in Ukrainian).

Slivinska, L., Fedorovych, V., Gutyj, B., Lychuk, M., Shcherbatyy, A., Gudyma, T., Chernushkin, B., \& Fedorovych, N. (2018). The occurrence of osteodystrophy in cows with chronic micronutrients deficiency. Ukrainian Journal of Ecology, 8(2), 24-32. doi: 10.15421/2018_305.

The methodology for determining the economic efficiency of the use in agriculture of the results of scientific research, new technology, inventions and rationalization proposals. M.: VAIIPI, 1983, 149 p. (inRussian).

Varcholyak, I. S., \& Gutyi, B. V. (2019). Determination of the chronic toxicity of preparation "Bendamin" on laboratory animals. Theoretical and Applied Veterinary Medicine, 7(2), 63-68. doi: 10.32819/2019.71011.

Yong, D., Hassell, T., \& Duongan, Y. (2002). Chronic factors infections: living with unwanted guests. Nature immunology, 3(11), 1026-1032. doi: 10.1038/ni11021026. 